\title{
Perencanaan Pembangunan Inklusif Melalui Peran Partisipatif Pemerintah Daerah
}

\author{
Ecces : \\ Economics Social and Development Studies
}

\author{
Sugianto ${ }^{1}$ \\ Yul Tito Permadhy ${ }^{2}$
}

Program Studi Ekonomi Pembangunan

Fakultas Ekonomi dan Bisnis UPN Veteran Jakarta

JL. RS. Fatmawati Pondok Labu No. 1 Jakarta, 12450, Indonesia

Email : sugiantosemm@yahoo.com ${ }^{1}$, madhyyul@yahoo.com ${ }^{2}$

(Article history) Received: 2020-04-26, Revised: 2020-04-30, Accepted: 2020-06-14, Available online: 2020-06-20 DOI: 10.24252/ecc.v7i1.13565

\section{Abstrak: Perencanaan Pembangunan Inklusif Melalui Peran Partisipatif Pemerintah Daerah.}

Pembangunan desa memegang peranan penting dan tidak terpisahkan dengan pembangunan nasional, terbukti adanya beberapa program pembangunan yang dirancang oleh pemerintah. Kabupaten Lebak terdiri atas 28 Kecamatan, meliputi 5 Kelurahan dan 340 Desa, diantaranya terdapat Desa Bojongcae dan Desa Cibadak. Kedua desa ini memiliki jumlah penduduk 3.499 jiwa dan 4.905 jiwa yang umumnya bekerja sebagai petani dan buruh tani, jika dilihat dari topografi kedua desa ini masih dikelilingi ladang dan sawah. Berdasarkan observasi, terlihat bahwa kedua Desa tersebut memiliki potensi untuk dijadikan desa wisata yang meliputi wisata kesenian, edukasi pertanian, perkebunan dan peternakan. Kedua desa ini berpotensi menyukseskan pembangunan daerah, kerena didukung adanya warga yang memiliki semangat perubahan. Penelitian menggunakan metode pendekatan rasionalistik, menjelaskan secara umum khusus dan semua ilmu pada metode berasal dari pemakaian intelektual yang dibangun di atas kemampuan argumentasi secara logik. Populasi penelitian adalah para kepala keluarga, tokoh masyarakat, dengan menggunakan sampel penelitian untuk satu Rukun Tetangga (RT) pada setiap desa akan diambil 5 responden. Untuk jumlah RT pada 2 desa sebanyak 31 RT, meliputi Desa Cibadak sebanyak 18 RT dan Desa Bojongcae sebanyak 13 RT, sehingga jumlah keseluruhan sampel responden 155 orang, pengumpulan data digunakan teknik mix method kuantitatif dan kualitatif, teknik analisis digunakan Analisis Statistik Inferensial, SWOT dan LQ. Hasil penelitian menunjukkan nilai prob>chi2 terdistribusi normal, sesuai dan terbukti valid, serta nilai LQ tertiggi 4,72 menunjukkan hasil sektor pertanian berpotensi, diharapkan pemerintahan desa dapat mengelola hasil pertanian dengan pemenuhan subsidi pupuk dari pemerintah pusat dapat mendukung hasil pertanian lebih maksimal.

Kata Kunci : Pembangunan Inklusif; Potensi Desa; Partisipasif; Pemerintah Daerah 


\section{Abstract: Inclusive Development Planning Through The Participatory Role of Local Government.}

Village development plays an important role and is inseparable from national development, as evidenced by the existence of several development programs designed by the government. Lebak Regency consists of 28 Districts, covering 5 Sub-districts and 340 Villages, including Bojongcae Village and Cibadak Village. These two villages have a population of 3,499 people and 4,905 people who generally work as farmers and farm laborers, if seen from the topography of the two villages, they are still surrounded by fields and rice fields. Based on observations, it appears that the two villages have the potential to become tourist villages which include art tourism, agricultural education, plantations and animal husbandry. These two villages have the potential to succeed in regional development, because they are supported by residents who have the spirit of change. Research uses the rationalistic approach, explains in general specifically and all the science of the method comes from intellectual use that is built on logical argumentation abilities. The study population is the heads of families, community leaders, using the study sample for one Neighborhood Association (RT) in each village 5 respondents will be taken. For the number of RTs in 2 villages, 31 RTs, including Cibadak Village, 18 RTs and Bojongcae Village, 13 RTs, so that the total sample of respondents was 155 people, quantitative and qualitative mix method data collection techniques, analytical techniques used Inferential Statistical Analysis, SWOT and LQ. The results showed that the prob> chi2 value was normally distributed, suitable and proven valid, and the highest LQ value was 4.72 indicating the potential agricultural sector results. It was hoped that the village government could manage agricultural products by fulfilling fertilizer subsidies from the central government to support agricultural output more optimally.

Keywoard : Inclusive Development; Village Potential; Participatory;Local Government

\section{PENDAHULUAN / INTRODUCTION}

Pembangunan daerah adalah bagian integral yang tidak terpisahkan dari pembangunan nasional, dimana berbagai kegiatan pembangunan telah terealisir oleh pemerintah pusat dimaksudkan untuk meningkatkan pembangunan nasional secara inklusif, begitu pula sebaliknya bahwa peningkatan pembangunan nasional diharapkan akan mendatangkan dampak positif terhadap pembangunan di daerah. Setiap pemerintahan daerah memiliki kebebasan dalam pembangunan daerahnya masing-masing, yang tertuang pada Undang-Undang No. 32 Tahun 2004, yaitu membahas mengenai pemerintah daerah yang berlandaskan asas prinsip otonomi menyeluruh (Rusdi, 2014).

Pelaksanaan pembangunan yang sukses akan berdampak pada pertumbuhan perekonomian suatu negara, jika dalam suatu negara terdapat banyak daerah-daerah terpencil dan angka kemiskinan yang tinggi, maka negara tersebut akan sulit berkembang bahkan sangat tidak mungkin untuk menjadi negara maju. Negara dengan angka kemiskinan yang tinggi dapat menyebabkan dampak ketimpangan pendapatan, serta 
muncul permasalahan perekonomian lainnya seperti pengangguran dan menurunnya angka kesehatan pada warga negara. Banyak hal yang dapat mempengaruhi keberhasilan proses kegiatan pembangunan pemerintahan suatu negara, salah satunya adalah upaya pembangunan desa-desa yang potensial pada suatu daerah di negara tersebut (Rusdi, 2014).

Desa merupakan perwujudan atau kesatuan geografi, sosial, ekonomi, politik, dan kultur yang terdapat di suatu daerah, serta pengaruhnya saling terkait pada daerah lainnya. Menurut Undang-Undang No. 22 Tahun 1999 mengenai pemerintah daerah pasal I Desa merupakan satu kesatuan masyarakat yang mempunyai kewenangan dalam kepentingan berdasarkan pengakuan sistem pemerintahan nasional di daerah (Bappenas, 2016). Selain itu tertuang pada Undang-Undang No. 32 Tahun 2004 mengenai kepemilikan batas wilayah.

Pembangunan desa menjadi hal yang penting dan tidak terpisahkan serta bersinergi terhadap pembangunan daerah/nasional. Terbukti banyaknya program pembangunan yang dirancang oleh pemerintah. Umumnya instansi pemerintah daerah mengakomodasi pembangunan desa pada program kerjanya. Tentunya berlandaskan pemahaman bahwa desa sebagai kesatuan geografis terdepan yang merupakan tempat sebagian besar penduduk bermukim. Dalam struktur pemerintahan, desa menempati posisi terbawah, akan tetapi justru terdepan dan langsung berada di tengah masyarakat, karenanya dapat dipastikan apapun bentuk setiap program pembangunan dari pemerintah akan selalu bermuara ke desa. Pemerintah desa didalam pembangunan pedesaan semestinya menjadi regulator serta memiliki peran sebagai pembuat kebijakan dan sebagai pelaksana program pembangunan (Dwiyanto 2009). Untuk mengoptimalkan potensi desa yang dimiliki, revitalisasi peran semua lembaga yang ada di desa sangat diperlukan (Bambang 2016).

Terkait peraturan menteri dalam Negeri No 66 tahun 2007 mengenai Perencanaan Pembangunan Desa, pembangunan di desa adalah model suatu Pembangunan partisipatif yaitu sistem pengelolaan pembangunan di desa secara musyawarah, mufakat dan gotong royong sesuai ciri masyarakat yang berakar budaya wilayah Indonesia. Tertuang pada pasal 5 Peraturan Menteri Dalam Negeri No 66 tahun 2007, Perencanaan pembangunan direncanakan dengan pemberdayaan dan partisipatif. Pemberdayaan adalah upaya mewujudkan kemampuan dan kemandirian masyarakat, sedangkan partisipatif adalah keterlibatan masyarakat secara aktif dalam proses pembangunan. Diharapkan dapat memberikan peningkatan perekonomian desa dengan bertambahnya sumber pendapatan desa dan meningkatnya produktifitas masyarakat setempat. (Bappenas, 2016). 
Potensi desa dilakukan untuk tersusunnya suatu peta rinci yang meliputi potensi sumberdaya air, sumberdaya manusia, sumberdaya financial, pengembangan wilayah, bidang ekonomi, bidang sosial budaya dan bidang pemerintahan (Bafdal et.al 2014). Kabupaten Lebak terletak pada provinsi Banten yang terdiri atas 28 Kecamatan, meliputi 5 kelurahan dan 340 desa, diantaranya terdapat Desa Bojongcae dan Desa Cibadak. Berdasarkan observasi peneliti, kedua desa ini memiliki jumlah penduduk 3.499 jiwa dan 4.905 jiwa.

Jika dilihat dari topografi kedua desa ini masih di kelilingi ladang dan sawah, oleh sebab itu umumnya penduduk berprofesi sebagai petani dan butuh tani, namun tak memungkiri adanya penduduk yang memilih bekerja pada bidang perdagangan, seperti halnya membuka usaha grosiran.

Desa Bojongcae dan Desa Cibadak sangat menarik untuk dilakukan penelitian dikarena peneliti meilihat terdapat adanya sumberdaya alam dan manusia yang mendukung untuk dikembangkannya lokasi wisata kesenian, pertanian, perkebunan dan peternakan, serta dengan pemanfaatan sumberdaya manusia kearah yang lebih produktif lagi, akan membantu proses pengolahan dan pemasaran semua aspek pendukung peningkatan pembangunan desa. Hal ini sama seperti program pembangunan desa yang dicanangkan oleh Presiden RI, jika pertumbuhan ekonomi diarahkan pada daerah-daerah yang memiliki potensi, fasilitas wilayah dan letaknya yang strategis, maka akan mempercepat terjadinya kemajuan ekonomi, dan mendorong negara tersebut menjadi negara maju. Oleh sebab itu peneliti akan melakukan pemetaan potensi desa berdasarkan aspek; 1). Sosial, EkonomiPolitik, dan Budaya, 2). Sumberdaya manusia-alam dan lingkungan, 3). Ideologi.

Berdasarkan hal tersebut, maka peneliti berasumsi bahwa kedua desa yaitu desa Cibadak dan Desa Bojongcae penting untuk dilakukan penelitian dalam pemetaan potensi desa tersebut. Kedua desa ini sangat berpotensi untuk menyukseskan pembangunan daerah Kabupaten Lebak provinsi Banten, karena didukung dengan adanya warga yang memiliki semangat perubahan ke arah yang lebih baik, namun demikian, pembangunan desa tidak hanya terpaku pada semangat warganya, tetapi juga perlu adanya pemetaan potensi desa sebagai tahap awal realisasi perencanaan pembangunan desa yang diharapkan akan timbul potensi-potensi dari segi ekonomi, sosial budaya, demografi, dan latar belakang politik, dengan dukungan partisipasi pemerintah desa yang dapat menggerakkan antusias masyarakat guna menghadapi inovasi di masa yang akan datang dan perubahan yang lebih baik lagi serta keberhasilan pembangunan desa. 


\section{TINJAUAN TEORITIK / LITERATURE REVIEW}

Desa merupakan kesatuan masyarakat yang memiliki wilayah hukum dengan batasbatas wilayah yang jelas. Pemerintahan daerah merupakan pelaksana kepemerintahan sebagai upaya menjalankan kepentingan masyarakat. Potensi desa dapat meningkatkan perekonomian penduduknya dan peran partisipasif pemerintah didalam perencanaan pembangunan dengan memberikan model penerapan strategi-strategi pembangunan potensi desa (Sugiyono, 2012; Arianto, 2020; Aprilita, 2013). Terkait hasil penelitian sebelumnya dengan mengidentifikasi berbagai bidang potensial yang secara ekonomi dapat diasumsikan sebagai leading sector dalam kerangka untuk menciptakan struktur ekonomi daerah yang lebih baik (Rusdi, 2014; Bambang, 2016; Prihatmaji, Fauzy, Firdaus, dan Subekti, 2015; Bafdal, Balia, Dwiratna dan Amaru, 2014).

Namun kemudian, persepektif itu berbeda dalam paparan Bappenas, yang kemudian memberikan perspektif yang lebih inklusif tentang pembangunan yang dimaknai sebagai perubahan yang disengaja atau direncanakan untuk mengubah keadaan yang tidak dikehendaki kearah yang dikehendaki. Pembangunan mengandung pengertian progresif atau bergerak yang maju dan menuju kesejahteraan, bukan retrogesif atau gerak yang mundur. Keseluruhan pembangunan desa yang mengedepankan kepentingan masyarakat, kepentingan nasional dengan tujuan kesejahteraan, pemerataan keadilan seluruh warga dengan cara penguatan kelembagaan sosial, penguatan tata nilai social capital masyarakat dan organisasi masyarakat. Penguatan ekonomi, penguatan faktor produksi, pendapatan, tabungan, pendidikan, keterampilan, kesehatan dan sikap mental (Bappenas, 2016). Permasalahan yang ada pada desa umumnya kurang meratanya pembangunan seperti infrastruktur desa yang belum memadai, jumlah sekolah yang terlalu sedikit, dan jarak tempuh sekolah dengan pemukiman sangat jauh, transportasi angkutan desa belum ada sehingga menyulitkan untuk mengikuti proses belajar, begitupula untuk menempuh ke jenjang berikutnya yang lebih tinggi, harus menempuh jarak lebih jauh ke kabupaten. Hasil literature review dengan mempertimbangkan peneliti sebelumnya dalam melihat potensi desa (Spear dan Roger, 2001; Seo dan Kim, 2013; Jessop, 1994; Wu dan Ban, 2012).

Kesanggupan dan kemampuan yang dimiliki oleh suatu desa yang mempunyai kemungkinan untuk dikembangkan dalam rangka meningkatkan kesejahteraan masyarakat. Potensi desa memerlukan partisipasi masyarakat agar lebih bertanggung jawab dalam 
Sugianto, Yul Tito Permadhy, Perencanaan Pembangunan Inklusif...

pembangunan desa, sehingga ada rasa memiliki terhadap desa tersebut dan hasil pembangunan tidak bertolak belakang dengan strategi pembangunan pemerintah pusat (Soleh, 2017). Pemerintah desa dalam penyelenggaraan desa sebagai perwujudan demokratis tentunya bekerjasa dengan Badan Pemusyawaratan Desa (BPD) untuk menilai kebijakan publik yang diinginkan terkait dengan Peraturan Menteri Dalam Negeri No. 114 Tahun 2014 dan Peraturan Menteri Dalam Negeri no. 37 Tahun 2007 bahwa peran pemerintah desa dan partisipasi masyarakat dalam pembangunan desanya (Dwiyanto,2019).

\section{METODE PENELITIAN / METHODS}

Penelitian ini menggunakan metode pendekatan rasionalistik, metode ini menjelaskan penelitian secara umum, khusus dan semua ilmu pada metode ini berasal dari pemakaian intelektual yang dibangun di atas kemampuan argumentasi secara logik dan valid (Sugiyono, 2012). Populasi dari penelitian ini adalah para kepala keluarga, tokoh masyarakat, pengusaha dan pejabat terkait di Desa Bojongcae dan Desa Cibadak, dengan menggunakan sampel penelitian untuk satu Rukun Tetangga pada setiap desa akan diambil lima responden. Untuk jumlah RT pada 2 (dua) desa sebanyak 31 (tiga puluh satu) RT, meliputi Desa Cibadak sebanyak 18 RT dan Desa Bojongcae sebanyak 13 RT, sehingga jumlah keseluruhan sampel responden 155 orang. Adapun penarikan sampel penelitian digunakan purposive sampling method, dimana sampel dipilih dengan dasar tertentu sesuai dengan tujuan penelitian dan data yang diperoleh merupakan data primer dan sekunder.

Penelitian ini menggunakan teknik analis kuantitatif dan kualitatif ( $m i x$ method) yang fokus pada kondisi lapangan dan masyarakat. Digunakannya analisis kuantitatif saat melakukan uji LQ, yang mana uji tersebut digunakan untuk melihat potensi yang unggul dalam bidang ekonomi Desa Bojongcae dan Desa Cibadak, dan digunakannya analisis kualitatif saat pengambilan data primer untuk mengetahui aspek oprasional variabel penelitian. Adapun operasional variabel yang digunakan dalam penelitian ini, beserta masing-masing indikatornya seperti terlihat pada tabel dibawah ini: 
Tabel 1. Operasionalisasi Variabel

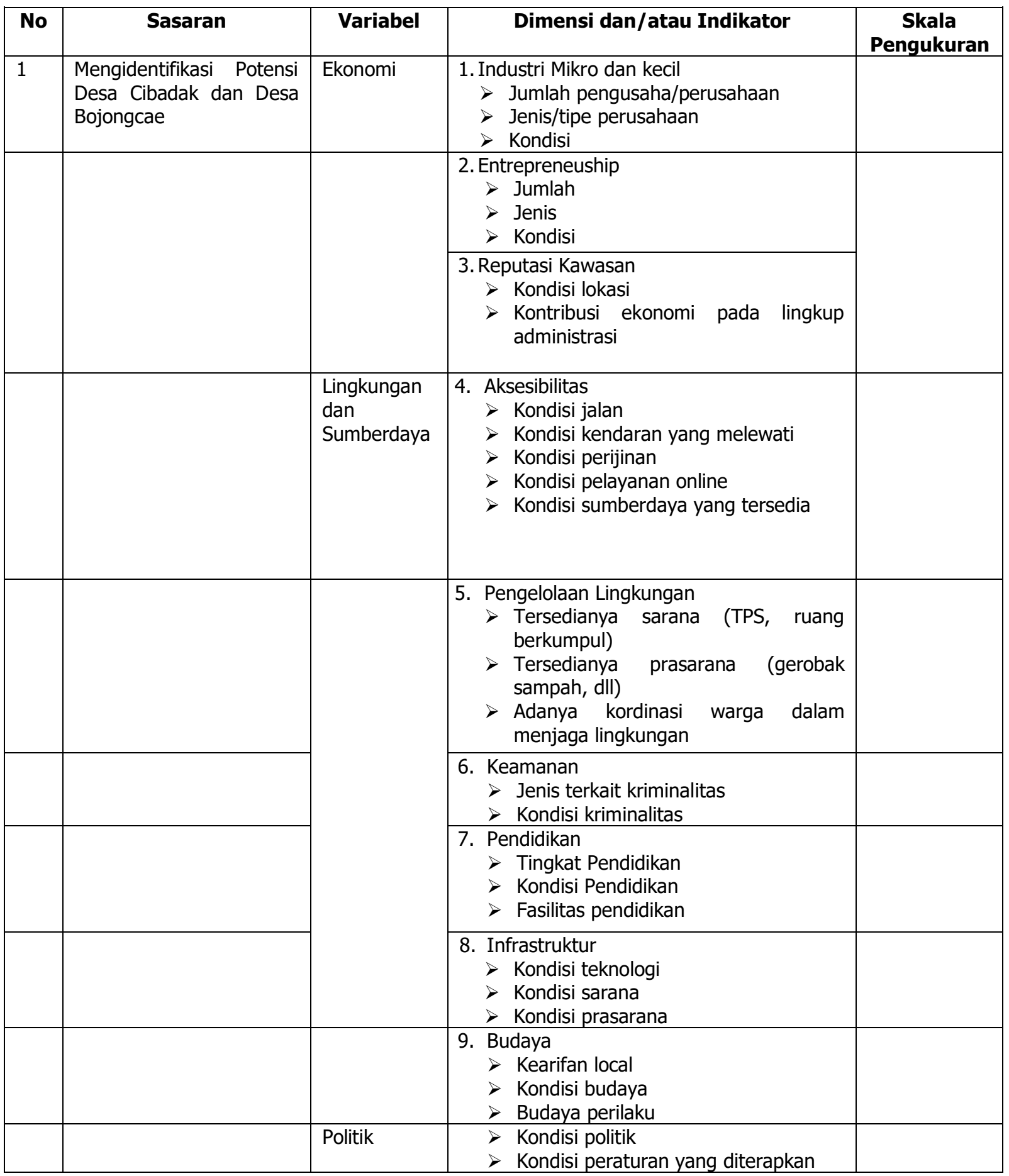




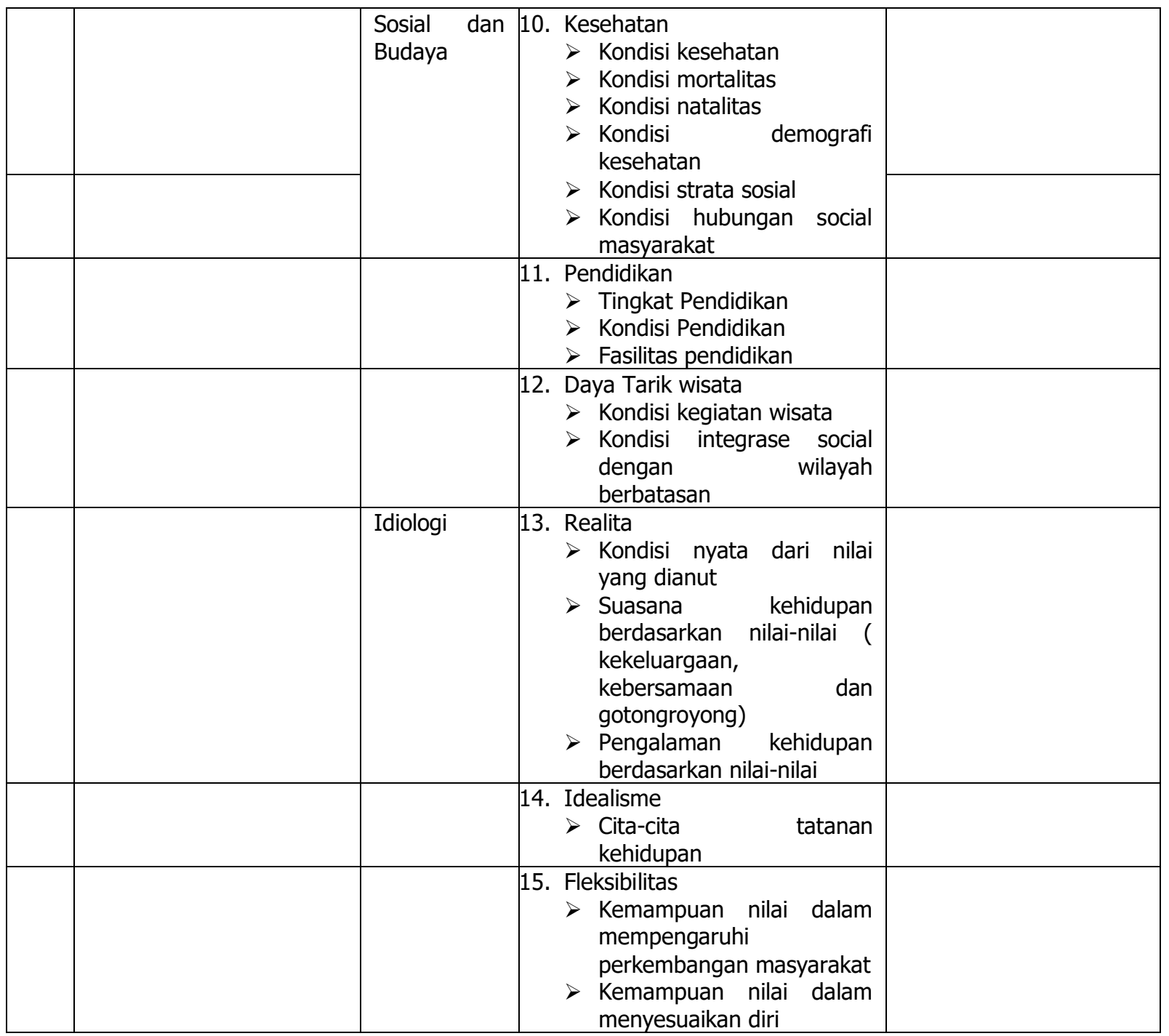

Sumber : Kumpulan jurnal penelitian terdahulu.

Pada penelitian ini metode analisis data yang digunakan antara lain Uji Normalias, Uji Validitas dan Analisa SWOT.

Tabel 2. Analisis SWOT

\begin{tabular}{|c|c|c|}
\hline EFAS & $\begin{array}{l}\text { STRENGTHS } \\
\text { Tentukan 5-10 Faktor-faktor kekuatan } \\
\text { Internal }\end{array}$ & $\begin{array}{l}\text { WEAKNESSES } \\
\text { Tentukan } 5-10 \text { Faktorfaktor kelemahar } \\
\text { Internal }\end{array}$ \\
\hline $\begin{array}{l}\text { OPPORTUNIES } \\
\text { Tentukan 5-10 Faktorfaktor peluang } \\
\text { Eksternal }\end{array}$ & $\begin{array}{l}\text { Strategi S/O Ciptakan strategi yang } \\
\text { menggunakan kekuatan } \\
\text { memanfaatkan peluang }\end{array}$ & $\begin{array}{l}\text { Strategi W/O Ciptakan strategi yang } \\
\text { meminimalkan kelemahan untuk } \\
\text { memanfaatkan peluang }\end{array}$ \\
\hline $\begin{array}{l}\text { TREASTHS } \\
\text { Tentukan } 5-10 \text { Faktor ancaman } \\
\text { Ekternal }\end{array}$ & $\begin{array}{l}\text { Strategi S/T Ciptakan strategi yang } \\
\text { menggunakan kekuatan } \\
\text { mengatasi ancaman }\end{array}$ & $\begin{array}{l}\text { Strategi } \mathrm{W} / \mathrm{T} \text { Ciptakan strategi yang } \\
\text { meminimalkan kelemahan dar } \\
\text { menghindari ancaman }\end{array}$ \\
\hline
\end{tabular}

Sumber : (Afrillita, 2013) 
Pendekatan LQ merupakan suatu teknik analisis untuk menentukan potensi spesialisasi suatu daerah terhadap aktifitas ekonomi yang utama, atau untuk menentukan sektor basis yaitu sektor ekonomi yang dapat untuk memenuhi kebutuhan daerah sendiri dan daerah lain.

Perumusan besarnya LQ dengan formulasi sebagai berikut (Wasil, 2012) :

$$
\mathbf{L Q}=\frac{\mathbf{v}_{\mathbf{i}} / \mathbf{v}_{\mathbf{t}}}{\mathbf{V}_{\mathbf{i}} / \mathbf{V}_{\mathbf{t}}}=\frac{\mathbf{v}_{\mathbf{i}} / \mathbf{V}_{\mathbf{i}}}{\mathbf{v}_{\mathbf{t}} / \mathbf{V}_{\mathbf{t}}}
$$

Keterangan :

vi : pendapatan sektor tertentu disuatu daerah

vt : pendapatan total daerah tersebut

Vi : pendapatan sektor sejenis secara regional

$\mathrm{Vt}$ : pendapatan total regional

Proxi tersebut selanjutnya disesuaikan dengan kondisi yang akan diteliti, sehingga (Wasil, 2012):

VI : PDRB masing-masing sektor/lapangan usaha di Kabupaten /Kota

vt : PDRB total Kabupaten /Kota

VI : PDRB propinsi masing-masing sektor atau lapangan usaha

Vt : PDRB propinsi secara total

Berdasarkan formulasi, maka jika (Wasil, 2012):

LQ>1, maka daerah lebih berspesialisasi pada sektor tersebut sehingga dapat melakukan ekspor.

$\mathrm{LQ}=0$, maka baik daerah maupun regional mempunyai tingkat spesialisasi yang tinggi.

LQ $<1$, maka bahwa daerah tidak memiliki spesialisasi pada sektor tersebut sehingga untuk memenuhi kebutuhan daerah sendiri mengimpor atau mendapat dari daerah lain.

Pada tahap ini setelah dilakukannya analisis SWOT, LQ dan Statistik Inferensial, selanjutnya akan diidentidikasi variabel-variabel keunggulan dan kelemahan berdasarkan prefensi masyarakat melalui FGD. Melalui hal tersebut diharapkan masyarakat dapat memberikan masukan berupa pemikiran dan keikutsertaannya dalam mengembangkan keunggulan desa yang dimiliki (peran partisipatif). 


\section{HASIL DAN PEMBAHASAN / DISCUSSION}

Hasil identifikasi potensi-potensi Desa Bojongcae dan Desa Cibadak dengan cara melakukan Forum Group Diskusi (FGD) bersama para aparat desa setempat, berdasarkan variabel ekonomi, lingkungan dan sumberdaya, politik, sosial budaya dan teknologi.

\section{Hasil Analisis Potensi Desa Bojongcae dan Desa Cibadak}

Melalui potensi desa yang memadai, akan membuatnya lebih mudah untuk menciptakan pembangunan nasional dan meningkatkan nilai pertumbuhan ekonomi suatu negara. Seperti apa yang terjadi di Indonesia, ada nawacita atau sembilan cita-cita rakyat Indonesia, salah satunya adalah membangun Indonesia dari pinggiran dengan memperkuat daerah dan desa dalam kerangka negara kesatuan.

Tabel 3. Hasil Potensi Desa Berdasarkan Variabel

\begin{tabular}{|c|c|c|c|}
\hline \multirow[t]{2}{*}{ No } & \multirow[t]{2}{*}{ Variabel } & \multicolumn{2}{|c|}{ Potensi yang ada } \\
\hline & & Desa Bojongcae & Desa Cibadak \\
\hline 1 & Ekonomi & $\begin{array}{l}\text { Pada desa ini tidak terdapat } \\
\text { perusahaan dalam negeri maupun } \\
\text { perusahaan asing yang berdiri, hanya } \\
\text { ada pelaku wirausaha yang bergerak } \\
\text { dalam bidang pertenakan (umbia). }\end{array}$ & $\begin{array}{l}\text { Pada desa ini tidak terdapat perusahaan } \\
\text { dalam negeri maupun perusahaan asing } \\
\text { yang berdiri, hanya ada pelaku } \\
\text { wirausaha seperti ; perbengkelan dan } \\
\text { laber jahe. }\end{array}$ \\
\hline 2 & $\begin{array}{ll}\text { Lingkungan } & \text { dan } \\
\text { Sumberdaya } & \end{array}$ & $\begin{array}{l}\text { Terdapat } 88 \text { Kepala keluarga, setiap } \\
\text { rumah sudah menggunakan listri } \\
\text { untuk penerangan. } \\
\text { Kondisi jalannya sangat tidak begitu } \\
\text { baik, dan bisa menimbulkan } \\
\text { kebanjiran, karena struktur tanahnya } \\
\text { tanah pasir dan kurang tersedianya } \\
\text { saluran untuk pembuangan air } \\
\text { hujan. } \\
\text { Persediaan air bersih pada desa ini } \\
\text { terbilang cukup sulit, sehingga warga } \\
\text { sering mengandalkan air hujan untuk } \\
\text { kebutuhan sehari-hari. } \\
\text { Sering terjadinya musim kemarau, } \\
\text { semingga petani kesulitan untuk } \\
\text { panen } \\
\text { Tidak adanya transportasi umum, } \\
\text { hanya menyediakan ojek pangkalan. } \\
\text { Tidak adanya jaringan internet, } \\
\text { provider yang memiliki sinyal yang } \\
\text { memadai hanyalah tekomsel }\end{array}$ & $\begin{array}{l}\text { Terdapat } 1.638 \mathrm{KK} \\
\text { Kondisi jalan sudah teraspal dengan } \\
\text { baik } \\
\text { Persedian air bersih pada desa ini } \\
\text { cukup memadai, namun pada saat } \\
\text { musim kemarau desa ini juga } \\
\text { mengalami kesulitan air bersih, sebab } \\
\text { sumber pengairan yang jauh. } \\
\text { Tidak adanya transportasi umum, } \\
\text { hanya menyediakan ojek pangkalan. } \\
\text { Adanya jaringan internet mandiri } \\
\text { seperti Fizta Nets } \\
\text { Adanya proses perizinan yang harus } \\
\text { dilakukan warga jika ingin membuka } \\
\text { izin perusahaan yang bertaraf Usaha } \\
\text { Mikro, Kecil dan Menengah (UMKM) } \\
\text { Adanya } 4 \text { kelompok petani } \\
\text { dan pembimbing penyuluh UPT } \\
\text { berupa ; padi dan palawija }\end{array}$ \\
\hline
\end{tabular}




\begin{tabular}{|c|c|c|c|}
\hline & & $\begin{array}{l}\text { Tidak pernah adanya pengurusan } \\
\text { izin untuk pembukaan usaha } \\
\text { perdagangan. } \\
\text { Untuk pembuangan sampah belum } \\
\text { ada dinas yang bekerja sama, dan } \\
\text { tidak ada tempat pembuangan } \\
\text { sampah yang khusus, sehingga } \\
\text { sampah-sampah tersebut hanya } \\
\text { dibakar saja } \\
\text { Adanya Perlindungan Masyarakat } \\
\text { (LIMNAS) dan Bintara Pembina Desa } \\
\text { (BABINSAS), sehingga tingkat } \\
\text { keamanan desa terjaga dan tidak } \\
\text { adanya tingkat kriminalitas yang } \\
\text { tinggi } \\
\text { Tidak tersedianya lapangan sebagai } \\
\text { salah satu sarana untuk berolah } \\
\text { raga. } \\
\text { Keunggulan tanaman yang ada di } \\
\text { desa ini seperti padi dan palawija }\end{array}$ & $\begin{array}{l}\text { Saat musim kemarau petani tidak bisa } \\
\text { bekerja, karena jauh dari irigasi } \\
\text { sehingga tidak adanya pengairan. } \\
\text { Untuk pembuangan sampah belum ada } \\
\text { dinas yang bekerja sama, dan tidak } \\
\text { ada tempat pembuangan sampah yang } \\
\text { khusus, sehingga sampah-sampah } \\
\text { tersebut hanya dibakar saja } \\
\text { Untuk perlindungan keamanan } \\
\text { terdapat Babinsar,Babinmas, dan babin } \\
\text { kamtipmas. Pihak-pihak yang berwajib } \\
\text { menjaga keamanan selalu tiap malam } \\
\text { melakukan patroli. } \\
\text { Berlakunya jam malam pada desa ini, } \\
\text { yaitu jam 10 malam semua warga } \\
\text { dilarang untuk keluar rumah tanpa } \\
\text { kepentingan tertentu. } \\
\text { Pada desa ini sudah tersedia fasilitas } \\
\text { untuk karang taruna berkumpul dan } \\
\text { berolahraga. } \\
\text { Keunggulan tanaman yang ada di desa } \\
\text { ini seperti padi dan palawija } \\
\text { Tanaman khas yang terdapat d desa } \\
\text { ini adalah jahe, sehingga dari desa ini } \\
\text { terkenal dengan produk wirausaha } \\
\text { "Laber Jahe" }\end{array}$ \\
\hline 3 & Politik & $\begin{array}{l}\text { Pada desa ini terdapat warga yang } \\
\text { berprofesi sebagai anggota dewan, } \\
\text { kepengurusan ranting parpol, dan } \\
\text { organisasi masyarakat seperti LSM }\end{array}$ & $\begin{array}{l}\text { Pada desa ini terdapat beberapa aktifis } \\
\text { parpol, adanya DPC, namun pihak LSM } \\
\text { tidak berperan aktif untuk mendukung } \\
\text { kegiatan pemerintah setempat }\end{array}$ \\
\hline 4 & Sosial dan Budaya & $\begin{array}{l}\text { Sektor perekonomian yang unggul } \\
\text { pada desa ini adalah sektor } \\
\text { pertanian, dengan total produksi } \\
1.657,5 \text { per ton/tahun. } \\
\text { Buah-buahan yang berpotensi } \\
\text { sebagai tanaman subur di desa ini } \\
\text { seperti ; mangga dengan produksi } \\
40 \mathrm{Kw} / \text { tahun, rambutan } 450 \mathrm{Kw} / \\
\text { tahun, duku } 7 \mathrm{Kw} / \text { tahun, durian } \\
150 \mathrm{Kw} / \text { tahun, jambu biji } 300 \mathrm{Kw} \\
\text { / tahun, papaya } 7 \mathrm{Kw} / \text { tahun, } \\
\text { pisang } 352 \mathrm{Kw} / \text { tahun, nanas } 5 \mathrm{Kw} \\
/ \text { tahun, nagka } 70 \mathrm{Kw} / \text { tahun, } \\
\text { Jambu air } 40 \mathrm{Kw} / \text { tahun, sukun } 6 \\
\mathrm{Kw} / \text { tahun, dan melinjo } 350 \mathrm{Kw} / \\
\text { tahun, } \\
\text { Pengolahan lahan pertanian sudah } \\
\text { menggunakan traktor, namun tidak } \\
\text { adanya pengairan dan tidak ada } \\
\text { pompa dr kali Ciujung yang } \\
\text { terdapat pada desa tersebut. }\end{array}$ & $\begin{array}{l}\text { Sektor perekonomian yang unggul } \\
\text { pada desa ini adalah sektor } \\
\text { pertanian, dengan total produksi } \\
812,2 \text { per ton/tahun. } \\
\text { Buah-buahan yang berpotensi } \\
\text { sebagai tanaman subur di desa ini } \\
\text { seperti ; mangga dengan produksi } 80 \\
\mathrm{Kw} / \text { tahun, rambutan } 450 \mathrm{Kw} \mathrm{/} \\
\text { tahun, duku } 7 \mathrm{Kw} / \text { tahun, durian } 150 \\
\mathrm{Kw} \mathrm{/} \mathrm{tahun,} \mathrm{jambu} \mathrm{biji} 200 \mathrm{Kw} / \\
\text { tahun, papaya } 6 \mathrm{Kw} / \text { tahun, pisang } \\
350 \mathrm{Kw} / \text { tahun, nanas } 5 \mathrm{Kw} / \text { tahun, } \\
\text { nagka } 80 \mathrm{Kw} / \text { tahun, jambu air } 40 \\
\mathrm{Kw} / \text { tahun, sukun } 7 \mathrm{Kw} / \text { tahun, dan } \\
\text { melinjo } 350 \mathrm{Kw} / \text { tahun. Desa ini } \\
\text { termasuk desa dengan urutan ke-2 } \\
\text { sebagai penghasil buah manga } \\
\text { sekecamatan Cibadak pada tahun } \\
\text { 2017. } \\
\text { Pengolahan lahan pertanian sudah } \\
\text { menggunakan traktor, dan pada desa } \\
\text { ini sering mendapat subsidi untuk } \\
\text { pupuk tanaman pertanian. }\end{array}$ \\
\hline
\end{tabular}




\begin{tabular}{|c|c|c|c|}
\hline & & 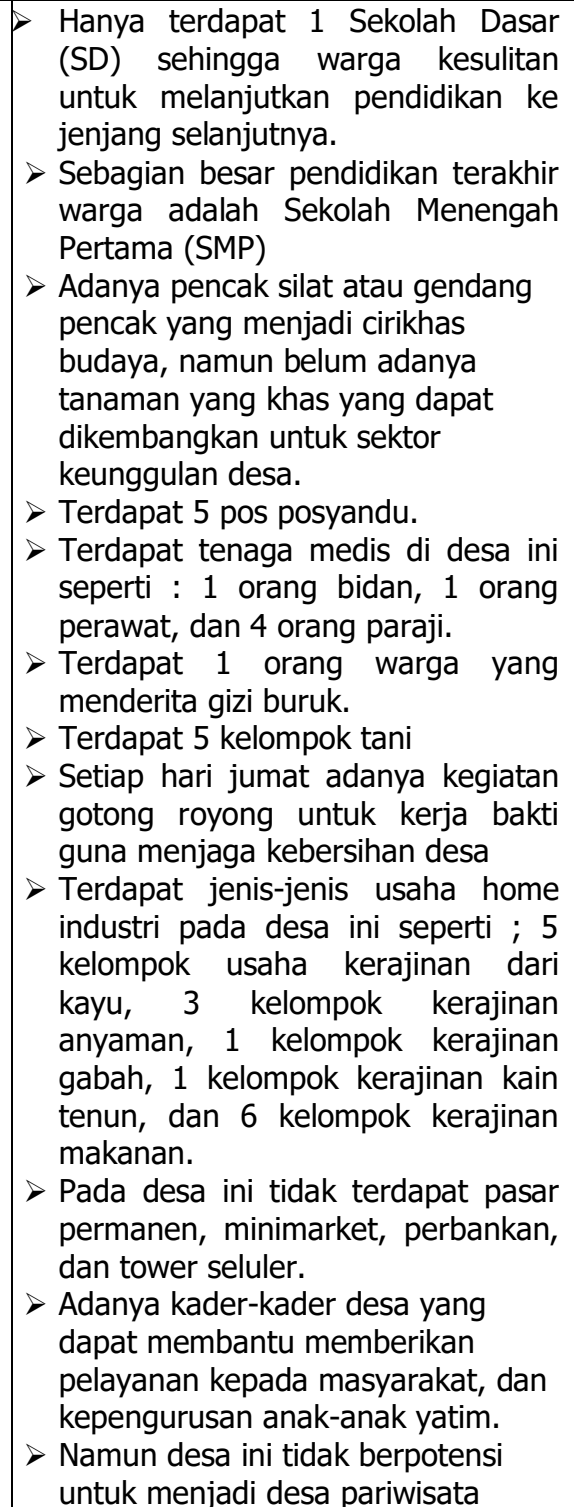 & $\begin{array}{l}\text { Pada desa ini terdapat fasilitas } \\
\text { pendidikan seperti } 2 \text { Sekolah Dasar } \\
\text { (SD), PAUD, dan } 2 \text { Sanawiyah. } \\
\text { Sebagian besar pendidikan terakhir } \\
\text { warga adalah Sekolah Menengah } \\
\text { Pertama (SMP) } \\
\text { Keseniannya budaya yang terdapat } \\
\text { pada desa ini adalah marawis dan } \\
\text { pencak silat pos posyandu yang, } \\
\text { Terdapat } 4 \text { pKK, namun } \\
\text { kelompok ibu-ibu PKK, } \\
\text { kegiatan karang taruna tidak } \\
\text { begitu aktif. } \\
\text { Terdapat tenaga medis di desa ini } \\
\text { seperti : } 1 \text { orang bidan, } 4 \text { orang } \\
\text { paraji, dan } 2 \text { orang tenaga urut } \\
\text { tradisional. } \\
\text { Terdapat } 2 \text { orang warga yang } \\
\text { menderita gizi buruk. } \\
\text { Setiap hari jumat adanya kegiatan } \\
\text { gotong royong untuk kerja bakti guna } \\
\text { menjaga kebersihan desa. } \\
\text { Terdapat jenis-jenis usaha home } \\
\text { industri pada desa ini seperti ; } 25 \\
\text { kelompok kerajinan dari kayu, } 5 \\
\text { kelompok kerajinan tenun, } 4 \\
\text { kelompok kerajinan makanan dan } 8 \\
\text { kelompok kerajinan lio bata. } \\
\text { Pada desa ini tidak terdapat pasar } \\
\text { permanen, minimarket, perbankan, } \\
\text { dan tower seluler. } \\
\text { Pada desa ini bisa berpotensi untuk } \\
\text { menjadi desa pengembangan } \\
\text { tanaman jahe, namun tidak } \\
\text { ditemukannya potensi wilayah } \\
\text { pariwisata. }\end{array}$ \\
\hline 5 & Idiologi & $\begin{array}{l}\text { Desa ini memiliki cita-cita tatanan } \\
\text { hidup kedepannya untuk menjadi } \\
\text { desa yang unggul di bidang } \\
\text { pertanian dan unggul dalam } \\
\text { kegiatan karang taruna } \\
\text { Desa ini ingin menumbuhkan } \\
\text { semangat belajar pada warga } \\
\text { dengan cara mendirikan Sekolah } \\
\text { Menengah Pertama, sebab masih } \\
\text { banyak warga yang enggan } \\
\text { melanjutkan pendidikan karena } \\
\text { terkendala jarak yang jauh untuk } \\
\text { ditempuh ke sekolah tersebut. } \\
\text { Desa ini ingin memiliki fasilitas } \\
\text { penunjang kesehatan berupa } \\
\text { ambulan, Kepala Desa sampai saat } \\
\text { ini terus mengusahakan agar ada } \\
\text { dana bantuan untuk pembelian } \\
\text { ambulan tersebut. }\end{array}$ & $\begin{array}{l}\text { Desa ini memiliki cita-cita untuk } \\
\text { menumbuhkan semangat jiwa } \\
\text { berwirausaha kepada warga } \\
\text { setempat, terutama untuk wanita } \\
\text { yang berprofesi sebagai ibu rumah } \\
\text { tangga, agar perekonomian keluarga } \\
\text { menjadi lebih baik. } \\
\text { Desa ini ingin menumbuhkan } \\
\text { semangat belajar bagi putra/putri } \\
\text { desa, setidaknya sampai jenjang } \\
\text { Sekolah Menengah Atas (SMA). }\end{array}$ \\
\hline
\end{tabular}




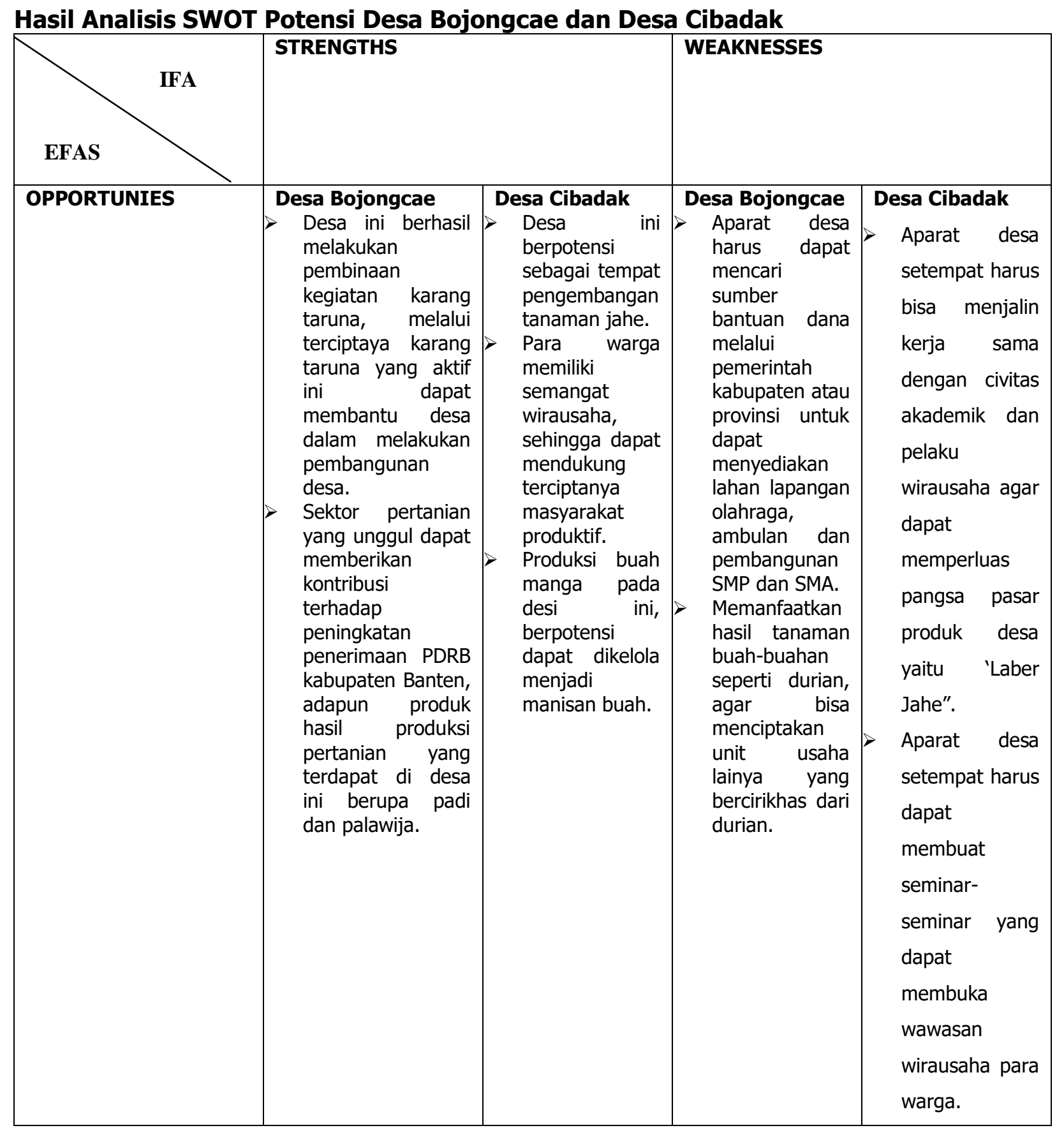




\begin{tabular}{|c|c|c|c|c|}
\hline TREASTHS & \begin{tabular}{|l}
\multicolumn{2}{|c}{ Desa Bojongcae } \\
Aparat desa harus \\
dapat \\
memberdayakan \\
para karang taruna, \\
dan membinanya \\
menjadi sebuah \\
kelompok Usaha \\
Kecil dan Menengah \\
agar dapat \\
meningkatkan \\
perekonomian desa. \\
Dengan kepala desa \\
yang masih berusia \\
muda, maka desa ini \\
harus dapat \\
membangkitkan \\
semangat para \\
warga-warga muda \\
untuk terus \\
melanjutkan jenjang \\
pendidikannya.
\end{tabular} & \begin{tabular}{|l} 
Desa Cibadak \\
Aparat desa harus \\
dapat \\
memasarkan hasil \\
produk "Laber \\
Jahe" secara \\
online dengan \\
bantuan jaringan \\
internet mandiri \\
yang ada di kantor \\
kepala desa. \\
Aparat desa harus \\
mengembangkan \\
kelompok seni \\
setempat, agar \\
bisa menjadikan \\
cirikhas desa.
\end{tabular} & $\begin{array}{l}\text { Desa Bojongcae } \\
\text { Aparat desa } \\
\text { harus bisa } \\
\text { menciptakan } \\
\text { lembaga } \\
\text { bimbingan } \\
\text { pembelajaran } \\
\text { atau lembara } \\
\text { belajar agar } \\
\text { tetap } \\
\text { mendorong } \\
\text { semangat warga } \\
\text { untuk bersekolah } \\
\text { walaupun letak } \\
\text { sekolah jauh, } \\
\text { adapun } \\
\text { menanggapi hal } \\
\text { tersebut maka } \\
\text { aparat desa } \\
\text { harus dapat } \\
\text { mengajukan } \\
\text { bantuan kepada } \\
\text { Kementrian } \\
\text { Pendidikan agar } \\
\text { desa ini terpilih } \\
\text { sebagai desa } \\
\text { yang harus } \\
\text { diberikan } \\
\text { bantuan tenaga } \\
\text { pendidik dan } \\
\text { tenaga } \\
\text { kesehatan, } \\
\text { sebab tenaga } \\
\text { kesehatan yang } \\
\text { terdapat di desa } \\
\text { ini masih berpola } \\
\text { tradisional. desa } \\
\text { Aparat desa } \\
\text { harus dapat } \\
\text { mampu gampan } \\
\text { mengurangi } \\
\text { penderita gizi } \\
\text { buruk, dengan } \\
\text { cara bekerja } \\
\text { sama dengan } \\
\text { dinas kesehatan } \\
\text { setempat untuk } \\
\text { melakukan } \\
\text { penyuluhan } \\
\text { kesehatan. }\end{array}$ & $\begin{array}{l}\text { Desa Cibadak } \\
\text { Aparat desa } \\
\text { harus dapat } \\
\text { memberikan } \\
\text { ide ataupun } \\
\text { sarana / } \\
\text { prasarana ntuk } \\
\text { mendukung } \\
\text { wirausaha } \\
\text { Aparat desa } \\
\text { harus dapat } \\
\text { menumbuhkan } \\
\text { semangat } \\
\text { warga untuk } \\
\text { aktif dalam } \\
\text { kegiatan } \\
\text { karang taruna. } \\
\text { Aparat desa } \\
\text { harus dapat } \\
\text { membudayaka } \\
\text { n kesenian } \\
\text { desa, agar } \\
\text { menjadi } \\
\text { cirikhas desa, } \\
\text { dan } \\
\text { menjadikan } \\
\text { festifal budaya } \\
\text { tahunan. }\end{array}$ \\
\hline
\end{tabular}




\section{Kekuatan (Strengths)}

Kedua desa ini memiliki sektor pertanian unggul dalam perekonomian, karena desa Bojongcae sangat terkenal dengan produk beras dan kelapa sawitnya, sedangkan untuk desa Cibadak selain beras dan tanaman sekunder, ada tanaman jahe yang merupakan produk unggulan UMKM. Karang Taruna dan lembaga masyarakat di desa Bojongcae sangat aktif untuk membantu pemerintah dalam pembangunan.

2. Kelemahan (Weaknesses)

Di desa Bojongcae tidak ada sektor yang memiliki potensi untuk dikembangkan menjadi daerah wisata, sedangkan di desa Cibadak ada perkebunan jahe yang berpotensi menjadi daerah wisata. Kurangnya fasilitas pendidikan di kedua desa ini, sehingga standar pendidikan di kedua desa ini rendah, tidak ada tempat irigasi dan pengelolaan limbah yang membuat kedua desa ini kering serta mudah tercemar oleh lingkungan. Untuk desa Bojongcae terdapat akses jalan yang rusak membuat warga sulit untuk melakukan kegiatan.

3. Kesempatan (Opportunity)

Desa Bojongcae dan desa Cibadak mampu memaksimalkan hasil pertanian dan harus dibantu oleh industri pengolahan. Limbah yang terkandung di kedua desa ini dapat dimaksimalkan untuk diproses sehingga dapat digunakan sebagai pupuk untuk tanaman dan hasil buah yang melimpah dari kedua desa ini berpotensi dapat menghasilkan buah manisan.

\section{Ancaman (Treath)}

Jarak sekolah terlalu jauh dari masing-masing kedua desa ini, akan menyebabkan tingkat antusiasme yang rendah untuk belajar dan melanjutkan ke tingkat berikutnya, sehingga di kedua desa ini akan ada kekurangan sumber daya manusia yang produktif. Kedua desa ini akan rentan terhadap kekeringan, karena sumber daya air yang tidak memadai dan jaringan internet yang tidak memadai dapat membuat sulit untuk membuka wawasan masyarakat tersebut.

\section{Analisis Location Quotient (LQ)}

Dalam penelitian ini, analisis LQ dihitung berdasarkan pendapatan domestik regional bruto (PDRB) pada tahun 2018. Hasilnya menunjukkan bahwa nilai LQ lebih dari 1, yang berarti bahwa daerah lebih terspesialisasi dalam sektor ini sehingga mereka dapat mengekspor, adalah sektor; pertanian, kehutanan dan perikanan, penambangan dan 


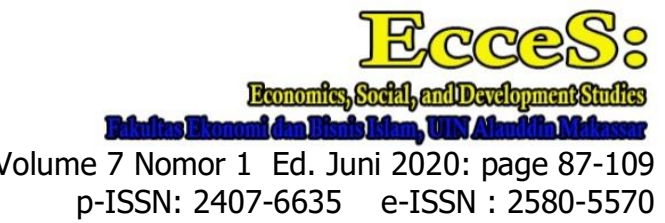

penggalian, konstruksi, perdagangan grosir dan eceran; perbaikan mobil dan sepeda motor, penyediaan akomodasi dan minuman, administrasi pemerintahan, pertahanan dan jaminan sosial wajib, layanan lainnya.

Untuk sektor yang memiliki nilai $L Q<1$, yang berarti bahwa wilayah tersebut tidak memiliki spesialisasi di sektor tersebut sehingga untuk memenuhi kebutuhan daerah itu sendiri, impor atau dapatkan dari daerah lain, adalah sektor tersebut; industri pengolahan, pengadaan listrik dan gas, pasokan air, pengelolaan limbah, limbah dan daur ulang, transportasi dan pergudangan, informasi dan komunikasi, layanan keuangan dan asuransi, real estate, layanan perusahaan, layanan pendidikan, layanan kesehatan, dan kegiatan sosial.

\section{Hasil Uji Statistik Peran Partisipatif Pemerintah Desa Bojongcae dan Desa Cibadak}

Pemerintah desa atau tepatnya kepala desa memiliki tugas mengatur urusan pemerintahan, pembangunan, dan kemasyarakatan. Urusan pemerintahan adalah pengaturan kehidupan masyarakat sesuai dengan kewenangan desa seperti pembuatan peraturan desa, pembentukan lembaga masyarakat, pembentukan perusahaan milik desa, dan kerjasama antar desa (Ulumiyah, Gani, \& Mindarti, 2016).

Peran pemerintah desa sangat dominan dalam pembangunan desa tersebut, pemerintah desa harus mampu untuk memfasilitasi segala kebutuhan publik dan hal-hal yang dapat menunjang kesejahteraan warga desa. Potensi desa tidak akan dapat tumbuh tanpa peran pemerintah desa, sehingga dalam pembahasan penelitian ini akan dipaparkan hasil analisis uji data statistik tentang peran pemerintah desa / kepala desa Bojongcae dan Cibadak dalam memberikan pelayan kepada masyarakat desa setempat, adapun data yang diperoleh oleh tim peneliti adalah hasil penilaian penduduk desa Bojongcae dan desa Cibadak dalam bentuk kuesioner. Dalam penelitian ini 83 responden pria dan 72 wanita. Usia responden yang rentan adalah 26 tahun hingga 41 tahun, karakteristik responden bekerja untuk 103 petani, 10 mekanik dan 42 pedagang.

Pertanyaan yang terkandung dalam kuesioner didasarkan pada aspek; kesesuaian jenis layanan, kemudahan, kecepatan, biaya, kemampuan petugas, kesopanan, serta keseluruhan layanan yang diberikan oleh masyarakat, dengan kategori pilihan berikut; 1) Tidak Patuh, 2) Kurang Patuh, 3) Tepat, 4) Sangat Cocok. 
Sugianto, Yul Tito Permadhy, Perencanaan Pembangunan Inklusif...
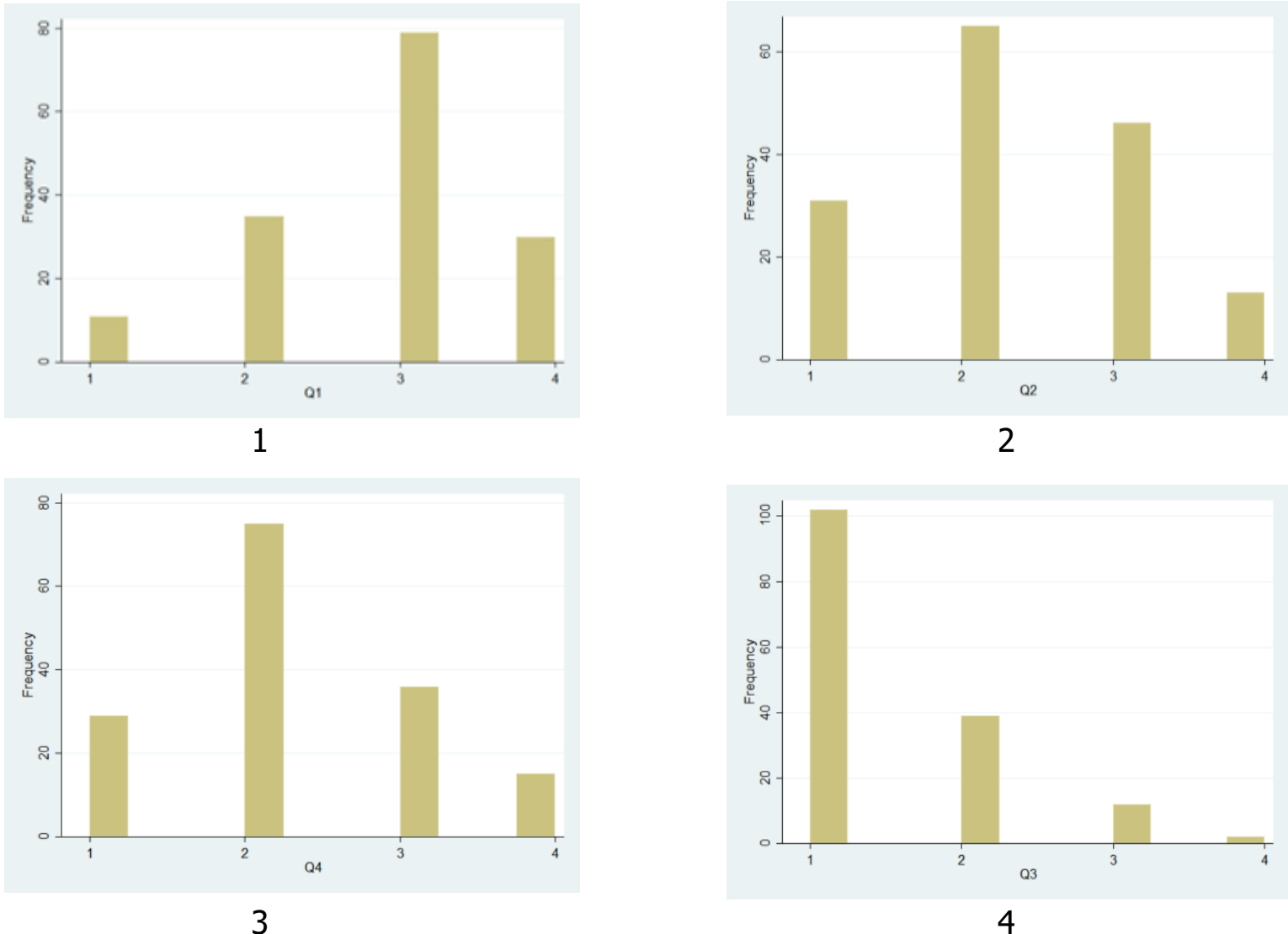

3

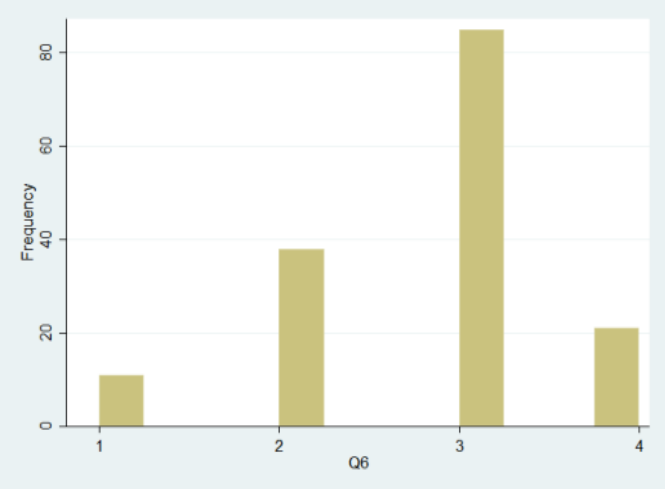

5

6

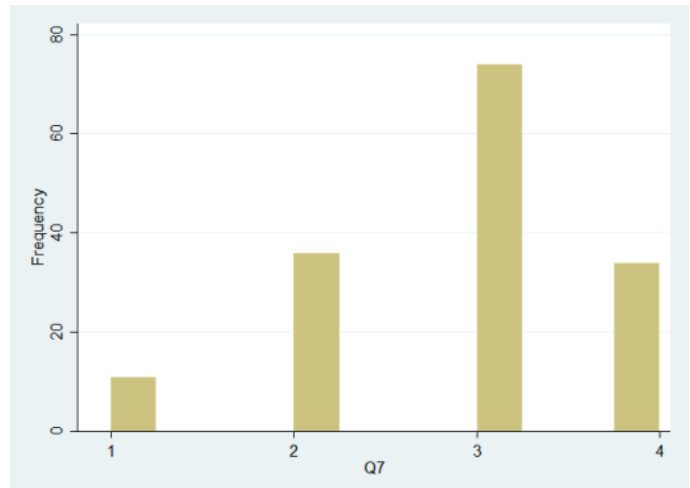

7

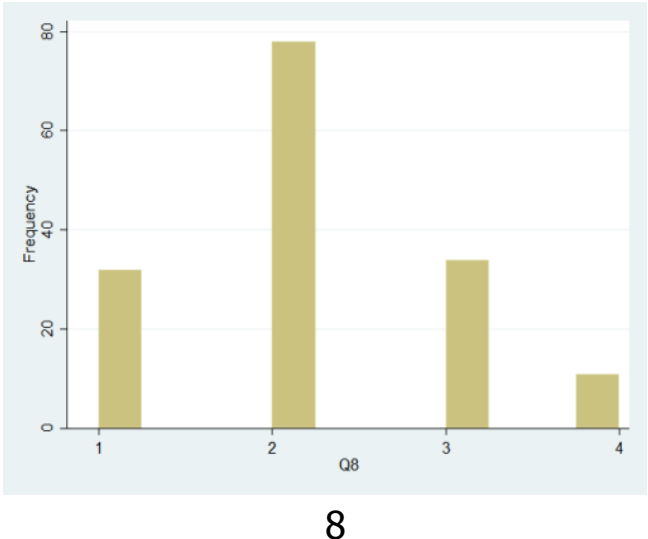




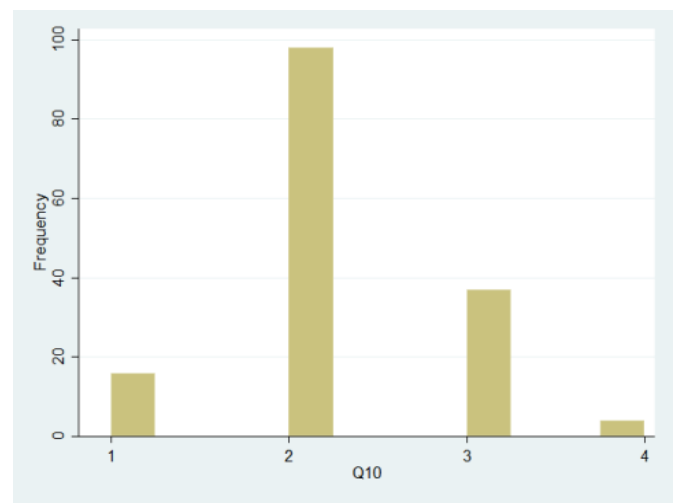

9

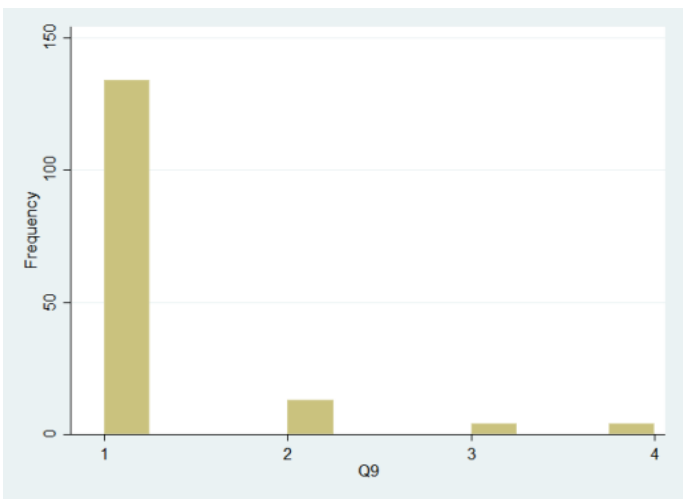

10

Berdasarkan gambar, dapat dilihat di bawah untuk pertanyaan pertama atau Q1 tentang kesesuaian persyaratan layanan dengan jenis layanan, sebagian besar responden menjawab sesuai, ini menunjukkan bahwa semua persyaratan yang ditetapkan oleh pemerintah desa dapat dipenuhi oleh masyarakat. Untuk pertanyaan kedua atau Q2 tentang kemudahan prosedur layanan, sebagian besar responden menjawab bahwa itu tidak tepat, ini menunjukkan bahwa masyarakat masih mengalami kesulitan dalam mendapatkan layanan, contoh masalah kesulitan yang ditemukan adalah masalah ketika mencetak surat, terkadang aparat pemerintah desa sulit memperbaiki mesin printer. Untuk pertanyaan ketiga atau Q3 tentang kecepatan layanan, mayoritas responden menjawab bahwa itu tidak tepat, ini menunjukkan bahwa pemerintah desa kurang responsif terhadap layanan yang telah dipesan oleh penduduk. Untuk pertanyaan keempat atau Q4 tentang kesesuaian antara biaya yang dibayarkan dan biaya yang telah ditetapkan, mayoritas responden menjawab bahwa itu tidak tepat, ini menunjukkan bahwa ada indikasi pembayaran biaya yang tidak ada dengan benar. Untuk pertanyaan kelima atau Q5 tentang kesesuaian antara hasil layanan yang diberikan dan kondisi yang ditentukan / permintaan pelanggan awal, sebagian besar responden menjawab itu sangat tepat, ini menunjukkan bahwa penduduk puas dengan layanan yang diusulkan di awal dan hasil yang mereka peroleh diterima.

Untuk pertanyaan keenam atau Q6 tentang kemampuan petugas untuk memberikan layanan, sebagian besar responden menjawab sesuai, ini menunjukkan bahwa apatarur yang bertanggung jawab adalah orang-orang yang cakap di sektor layanan. Untuk pertanyaan ketujuh atau Q7 tentang sikap (kesopanan dan keramahan) petugas dalam memberikan layanan, sebagian besar responden menjawab sesuai, ini menunjukkan bahwa aparatur pemerintah memiliki etos kerja yang baik. Untuk pertanyaan kedelapan atau Q8 
mengenai kesesuaian implementasi layanan yang disediakan dengan yang ditetapkan (standar layanan) yang ditetapkan, sebagian besar responden menjawab bahwa itu tidak tepat, ini menunjukkan bahwa ada petugas yang tidak disiplin dalam melaksanakan Pekerjaan Pekerja. Standar. Untuk pertanyaan kesembilan atau Q9 tentang penanganan keluhan dan saran, sebagian besar responden menjawab bahwa itu tidak tepat, ini menunjukkan bahwa kritik atau saran yang diberikan oleh penduduk di kotak saran atau dikirim langsung ke aparat pemerintah desa tidak disadari, dan untuk pertanyaan terakhir atau Q10 tentang persepsi kepuasan layanan secara keseluruhan, sebagian besar responden menjawab bahwa itu tidak tepat, ini menunjukkan bahwa penduduk desa Bojongcae dan desa Cibadak masih merasa tidak puas dengan layanan yang diberikan oleh pejabat pemerintah desa setempat, seperti pengumpulan biaya. sukarela, kurangnya layanan yang diberikan sehingga warga harus menunggu lama atau bahkan datang berkali-kali, dan kritik serta saran yang tidak didengar.

\section{Hasil Uji Normalitas}

\begin{tabular}{|c|c|c|c|c|c|c|}
\hline Variable & Obs & $\operatorname{Pr}($ Skewness $)$ & $\operatorname{Pr}($ Kurtosis) & $\operatorname{adj}$ & $\operatorname{chi2}(2)$ & Prob>chi2 \\
\hline q1 & 155 & 0.0246 & 0.7172 & & 5.16 & 0.0758 \\
\hline q2 & 155 & 0.2548 & 0.0230 & & 6.19 & 0.0454 \\
\hline$q^{3}$ & 155 & 0.0000 & 0.0042 & & 33.63 & 0.0000 \\
\hline $\mathrm{q} 4$ & 155 & 0.0336 & 0.2679 & & 5.61 & 0.0605 \\
\hline q5 & 155 & 0.0000 & 0.0000 & & . & 0.0000 \\
\hline q6 & 155 & 0.0231 & 0.8448 & & 5.17 & 0.0753 \\
\hline q7 & 155 & 0.0353 & 0.3561 & & 5.24 & 0.0727 \\
\hline q8 & 155 & 0.0205 & 0.6726 & & 5.45 & 0.0654 \\
\hline q9 & 155 & 0.0000 & 0.0000 & & . & 0.0000 \\
\hline q10 & 155 & 0.0398 & 0.1691 & & 5.91 & 0.0520 \\
\hline
\end{tabular}

sumber: data diolah

Berdasarkan tabel di atas diketahui bahwa hasil uji normalitas dari 10 pertanyaan mengenai kualitas pelayanan yang telah diberikan oleh pemeritahan desa Bojongcae dan Cibadak kepada masyarakat setempat, terdapat 6 pertanyaan yang terdistribusi normal dan 4 pertanyaan yang tidak terbistribusi normal, diantaranya adalah pertanyaan nomor 2, 3, 5, dan 9. Pertanyaan-pertanyaan tersebut dikategorikan terdistribusi normal jika nilai Prob>chi2 lebih besar dari standar kepercayaan yaitu 5\%, begitu juga sebaliknya jika nilai Prob>chi2 lebih kecil dari standar kepercayaan yaitu 5\% maka dapat dikatakan bahwa pertanyaan tersebut tidak terdistribusi normal. Pertanyaan 2,3,5, dan 9 tidak terdistribusi 
normal dikarenakan jumlah rentan pilihan jawaban yang telah dipilih oleh responden tidak merata antara pilihan 1 sampai dengan 4, yang dimana kategori pilihan 1 adalah untuk karegori tidak sesuai, pilihan 2 adalah untuk karegori kurang sesuai, pilihan 3 adalah untuk karegori sesuai dan pilihan terakhir yaitu 4 adalah pilihan untuk kategori sangat sesuai.

Sebagian dari nilai kurtosis dapat diketahui bahwa lebih besar dari 0,263, maka dapat dikategorikan kedalam distribusi leptokurtik, yang berarti distribusi ini menyempit pada bagian pucaknya atau mendekati runcing. Keadaan ini menunjukkan bahwa frekuensi cenderung tertumpuk pada daerah sekitar nilai mean atau menunjukkan hanya sedikit frekuensi yang menyebar lebih jauh dari nilai tendensi pusat, dan berdasarkan tabel 4.8 juga diketahui bahwa untuk pertanaan 1 sampai dengan 10 nikai skewness nya berada pada rentang $-1,96$ dan $+1,96$, maka berarti data mendekati simetris (Arianto, 2010).

\section{Hasil Uji Validitas}

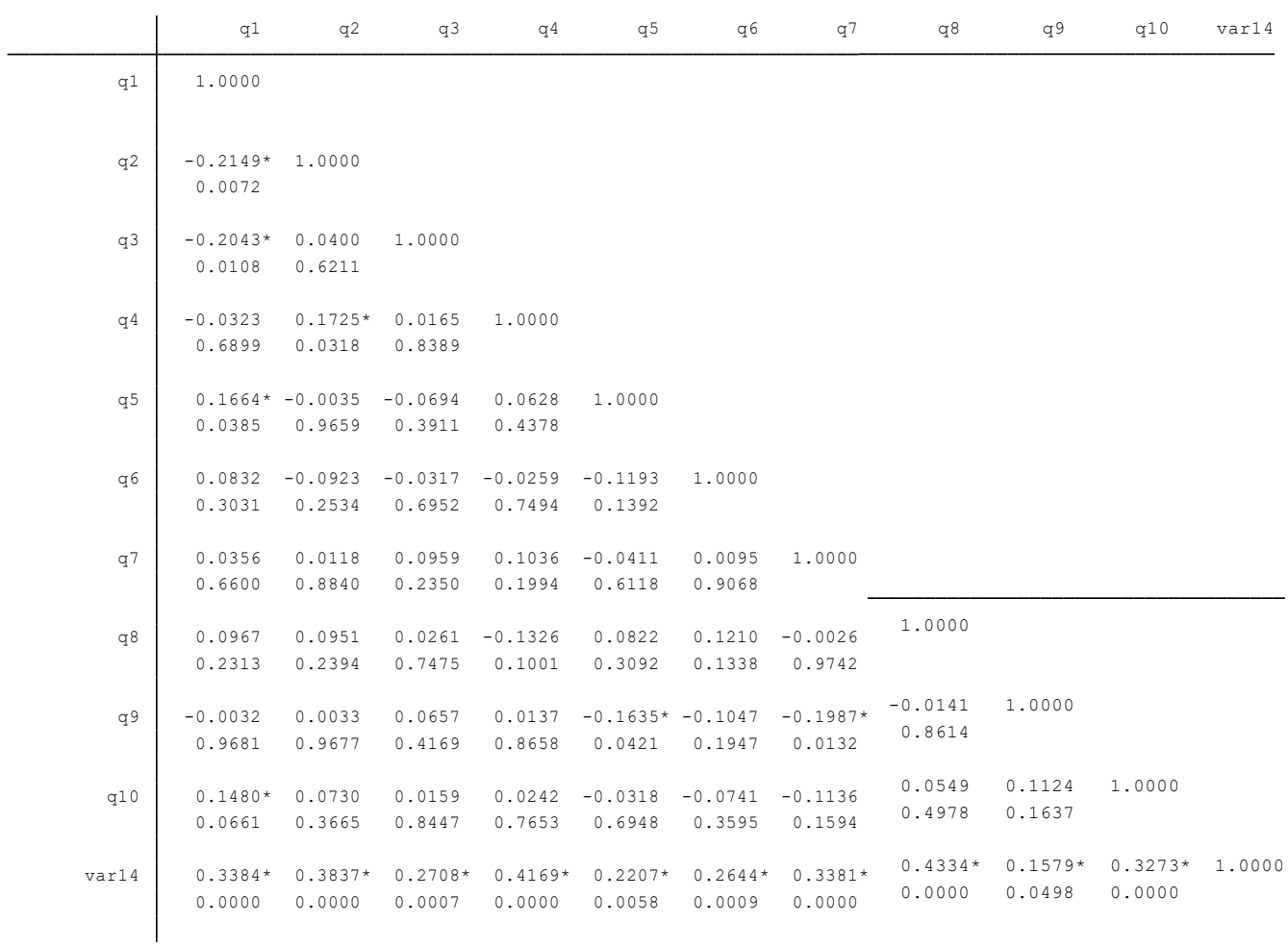

Uji validitas yang dilakukan oleh tim peneliti menggunakan uji pearson correlation test atau pairwise test. Dapat dilihat bawah pada var14 semua butir pertanyaan, yaitu dari Q1 sampai dengan Q10 terdapat tanda bintang $\left(^{*}\right)$, hal ini menandakan bahwa semua pertanyaan yang disajikan oleh tim peneliti sudah terbukti valid pada tingkat kepercayaan $1 \%, 5 \%$, dan $10 \%$. 


\section{KESIMPULAN / CONCLUSION}

Desa Bojongcae dan Desa Cibadak keduanya memiliki potensi perekonomian pada sektor pertanian. Hasil produksi tani yang unggul pada kedua desa ini adalah padi dan palawija. Hasil analisis LQ pun menunjukan bahwa sektor pertanian merupakan sektor unggul yang berpotensi untuk memproduksi barang untuk diimpor. Adapun kesenian budaya yang terdapat pada kedua desa ini yaitu adanya pencak silat, gendang pecak, dan marawis. Pada Desa Cibadak memiliki tanaman khas, yaitu jahe, hingga saat ini hasil produksi jahe dikemas dalam bentuk minuman sedu "Laber Jahe" .

Pada Desa Bojongcae tidak tersedia layanan internet yang memadai dan tidak adanya angkutan umum yang tersedia sebagai alat transportasi, yang ada hanyalah tukang ojek pangkalan, selain itu juga infrastruktur jalannya tidak baik, banyak jalan yang berlubang, dan desa ini masih kesulitan air bersih dan pengairan untuk sawah. Keadaan sebaliknya ditemukan pada Desa Cibadak, Desa Cibadak sudah ada layanan internet mandiri seperti Fizta Nets, namun tidak tersedianya alat transportasi umum, infrastruktur jalan pada Desa Cibadak terbilang baik dan tidak terlalu sering desa ini dilanda kemarau.

Tidak adanya Sekolah Menengah Pertama (SMP) pada Desa Bojoncae, sehingga menyebabkan sebagian besar warganya hanya berpendidikan Sekolah Dasar (SD), keadaan lain terjadi pada Desa Cibadak yaitu pada desa ini masih tersedianya Tsanawiyah, sehingga penduduk yang ingin melanjutkan pendidikan tidak terlalu sulit.

Warga Desa Bojongcae dan Desa Cibadak masih merasa kurang puas atas pelayanan yang selama ini diberikan oleh aparatur pemerintahan desa setempat, seperti halnya pemungutan biaya sukarela, kurang cepatnya pelayanan yang diberikan sehingga warga harus menunggu lama atau bahkan sampat datang berkali-kali, kritik dan saran yang kurang didengarkan.

Sebagai saran, pemerintah desa setempat sebaiknya bisa mengelola hasil pertanian dengan bantuan industri pengolahan agar hasil pertanian bisa bertahan lebih lama dan membuat peluang untuk diekspor ke luar negeri, pemerintah desa harus mengajukan subsidi pupuk yang lebih banyak lagi agar dapat mendukung hasil pertanian yang baik, pemerintah desa dapat melestarikan kesenian budaya desa agar tidak mudah punah ditengah era milenial seperti saat ini, Pemerintah Desa Cibadak sebaiknya bekerja sama dengan pihakpihak eksternal agar dapat memasarkan produk "Laber Jahe" secara online dan Pemerintah Pusat harus lebih memperhatikan SDM yang terdapat dikedua desa tersebut, sebab jenjang pendidikan terakhir yang warga miliki masih terlalu rendah. 


\section{DAFTAR PUSTAKA / REFERENCES}

Aprillita, N. 2013. Analisis Swot Dalam Menentukan Strategi Pemasaran Sepeda Motor Pada PT. Samekarindo Indah Di Samarinda. eJournal Administrasi Bisnis.

Arianto, A. 2010. Statistik Konsep Dasar, Aplikasi, dan Pengembangannya. Jakarta: Kencana Prenada Media Group.

Bafdal, N., Balia, R., Dwiratna, \& Amaru, K. 2014. A. Penyusunan Peta Potensi Desa Agrowisata Berbasis Masya Rakat Di Desa Cibuntu Kecamatan Pasawahan Kabupaten Kuningan. Jurnal Aplikasi Ipteks Untuk Masyarakat .

Bambang. 2016. Pemetaan Potensi Desa Di Kabupaten Banyumas. Jurnal Ilmu Ekonomi Fakultas Ekonomi dan Bisnis Islam UIN Alaudin Makasar, Vol. 3 NO. 2, Desember 2016 ISSN 2407-6635.

Bappenas. 2016. Laporan Akhir Kegiatan Kajian Penyusunan Instrumen Evaluasi Pembangunan Perdesaan (Lingkup Desa) . Jakarta: Bappenas.

Dwiyanto, H. 2009. Peran Pemerintah Dalam Pembangunan Pedesaan Di Desa Kandangan, Kecamatan Kandangan, Kabupaten Temanggung.

Jessop, B. 1994. The Transition to Post-Fordism and the Schumpeterian Workfare State' in

R. burrows \& B Loader(eds.), Towards A Post-Fordist Welfare State. London:

Routledge.

K. W., \& ed. 1978. The Political Economy of Development and Underdevelopment, second edition. New York.: Random House.

Peraturan Menteri Dalam Negeri No. 37 Tahun 2007. Pedoman Pengelolaan Keuangan Desa.

Peraturan Menteri Dalam Negeri No. 66 Tahun 2007. Tentang Perencanaan Pembangunan Desa.

Peraturan Menteri Dalam Negeri No. 114 Tahun 2014. Tentang Pedoman Pembangunan Desa.

Prihatmaji, Y., Fauzy, A., Firdaus, F., \& Subekti, M. 2015. Evaluasi Dan Pemetaan Potensi Desa Mitra Dppm UII. Jurnal Inovasi dan Kewirausahaan.

Rasyid, A. 2016. Analisis Potensi Sektor Potensi Pertanian Di Kabupaten Kediri Tahun 20102014. Jurnal Ekonomi Pembangunan Vol.14, No.02.

Rusdi, M. 2014. Analisis Data Sekunder Dalam Pemetaan Potensi Ekonomi Berbasis Kelurahan Atau Desa Di Kabupaten Buru. Jurnal Societas Fisip , 1-2. 
Soleh, A. 2017. Strategi Pengembangan Potensi Desa. Jurnal Sungkai Vol.5, No.1, , 32-52. Sugiyono. 2012. Metode Penelitian Kuantitatif dan Kualitatif dan R\&D. Bandung: C.V.

Suryawati, C. 2005. Memahami Kemiskinan secara multidimensional.

Sutrisno, E. 2011. Manajemen Sumberdaya Manusia. Jakarta: Kencana.

Spear, Roger. 2001. United Kingdom: A wide range of social enterprise. Carlo Borzaga \& Jacques Defourny, edited by, The Emergence of Social Enterprise, Routledg. pp. 252-269.

Seo, J and S. Kim. 2013. Operating Program Development for Rural-Urban Exchange Revitalization in Mountain Village. The Journal of Korean Institute of Forest Recreation 17(3): 53-63.

Undang-Undang Republik Indonesia No. 22 tahun 2004. Tentang Pemerintahan Daerah Undang-Undang Republik Indonesia No. 32 tahun 2004.

Ulumiyah, I., Gani, A., \& Mindarti , L. 2012. Peran Pemerintah Desa Dalam Memberdayakan Masyarakat Desa. Jurusan Administrasi Publik, Fakultas Ilmu Administrasi, Universitas Brawijaya, Malang .

Wasil, M. 2012. Pemetaan Potensi Wilayah Dan Pengembangan Produk Unggulan Sebagai Upaya Peningkatkan Ekonomi Masyrakat (Studi Pada Malang Utara). Laporan Penelitian Internal.

Wu, J. and G. Ban. 2012. Status and development projects of Village Enterprises in Chung Buk, Chung Buk Focus 59. 